\title{
Model Pembelajaran Cooperatif Integrated Reading Composition (CIRC) Meningkatkan Kemampuan Membaca Pemahaman Siswa
}

\author{
Heni Adawiyah ${ }^{1}$, I Ketut Gading ${ }^{2}$, Gede Wira Bayu ${ }^{3}$ \\ 1,3 Prodi Pendidikan Guru Sekolah Dasar, Universitas Pendidikan Ganesha, \\ Singaraja, Bali, Indonesia \\ 2 Prodi Bimbingan Konseling, Universitas Pendidikan Ganesha, \\ Singaraja, Bali, Indonesia \\ e-mail: heni.adawiyah02@gmail.com, Iketutgading@undiksha.ac.id,wira.bayu@undiksha.ac.id
}

\begin{abstract}
Abstrak
Penelitian ini dilatarbelakangi oleh rendahnya minat baca siswa yang menyebabkan kemampuan membaca pemahaman siswa menjadi rendah. Berdasarkan hasil observasi dan wawancara dengan Guru kelas IV di sekolah tempat penelitian mengetahui hasil bahwa masih ada beberapa siswa yang membacanya secara terbata-bata, bahkan ada siswa kelas IV yang belum bisa membaca, dengan demikian akan menjadi penghambat atau permasalahan siswa dalam mengikuti proses pembelajaran.Penelitian ini bertujuan untuk menganalisis model pembelajaran Cooperatif Integrated Reading Composition (CIRC) terhadap kemampuan membaca pemahaman siswa kelas IV SD. Jenis penelitian ini adalah penelitian pra-eksperimental. Desain yang digunakan pada penelitian ini adalah One Shot-Case Study. Populasi penelitian ini berjumlah 178 siswa yang tersebar pada 7 sekolah, sedangkan sampel berjumlah 35 siswa. Adapun teknik pengambilan sampel ini dilakukan dengan cara yaitu, menulis nama kelas yang menjadi populasi pada kertas sampai semua nama kelas IV yang menjadi populasi tersebut ditulis, kertas tersebut kemudian dilipat atau diremas hingga tulisannya tidak terlihat, ambil satu kertas tersebut untuk memilih sampel yang akan digunakan sebagai kelas eksperimen. Sampel dalam penelitian ini akan mendapatkan perlakuan berupa penerapan Model Pembelajaran Cooperatif Integrated Reading Composition(CIRC) dalam proses pembelajarannya. Data Kemampuan membaca pemahaman siswa dikumpulkan dengan menggunakan tes pilihan ganda mata pelajaran bahasa Indonesia yang sesuai dengan indikator kemampuan membaca pemahaman. Data yang diperoleh dianalisis dengan statistika inferensial (Uji T Burning). Hasil penelitian disimpulkan bahwa terdapat pengaruh yang signifikan model pembelajaran Cooperatif Integrated Reading Composition (CIRC) terhadap kemampuan membaca pemahaman siswa kelas IV SD didapat (nilai signifikansi $=0,000<0,05$ ).
\end{abstract}

Kata kunci: membaca pemahaman, CIRC, One-Shot Case Study.

\begin{abstract}
This research is motivated by the low interest in reading students which causes the students' reading comprehension ability to be low. Based on the results of observations and interviews with the fourth grade teacher at the school where the study knows the results that there are still some students who read it haltingly, there are even fourth grade students who have not been able to read, thus becoming an obstacle or problem for students in following the learning process. This study aims to analyze the Cooperative Integrated Reading Composition (CIRC) learning model on the reading comprehension skills of grade IV elementary school students. This type of research is a pre-experimental research. The design used in this study is the One Shot Case Study. The population of this study was 178 students spread over 7 schools, while the sample was 35 students. The
\end{abstract}




\begin{abstract}
sampling technique is done in a way that is, write the name of the class that is a population on paper until all the names of class IV that become the population are written, the paper is then folded or kneaded until the writing is not visible, take one piece of paper to choose the sample to be used as an experimental class. The sample in this study will get treatment in the form of the application of the Integrated Reading Composition Cooperative Learning Model (CIRC) in the learning process. Data Students' reading comprehension ability was collected using a multiple choice test of Indonesian subjects in accordance with indicators of reading comprehension skills. The data obtained were analyzed by inferential statistics (Burning T Test). The results of the study concluded that there was a significant influence on the Cooperative Integrated Reading Composition (CIRC) learning model on the reading comprehension ability of grade IV elementary school students (significance value $=0,000<0.05$ ).
\end{abstract}

Keywords: Reading comprehension, CIRC, One Shot-Case Study.

\title{
1. Pendahuluan
}

Bahasa Indonesia merupakan bahasa yang diresmikan penggunaannya setelah Proklamasi Kemerdekaan Indonesia dan bahasa Indonesia memiliki kedudukan sebagai bahasa nasional dan bahasa negara. Melihat kedudukannya sebagai bahasa nasional, (Dibia, 2007)mengungkapkan bahwa terdapat fungsi bahasa Indonesia sebagai bahasa nasional yaitu sebagai lambang jati diri (identitas), lambang kebanggaan bangsa, alat pemersatu berbagai masayarakat yang mempunyai latar belakang etnis dan sosial-budaya, serta bahasa daerah yang berbeda, dan sebagai alat penghubung antar budaya dan antar daerah. Berdasarkan hal tersebut, maka bahasa Indonesia merupakan salah satu aspek yang penting untuk dibelajarkan di jenjang pendidikan. Keberhasilan belajar siswa sangat dipengaruhi oleh kemampuannya dalam berbahasa. Kariesma (2014) menyatakan pada pembelajaran bahasa Indonesia, siswa diarahkan untuk berkomunikasi dengan bahasa Indonesia yang baik dan benar, bahasa Indonesia yang baik berarti mampu menggunakan bahasa dengan situasi dan kondisi pemakainya, sedangkan bahasa Indonesia yang benar menggunakan bahasa Indonesia dengan tepat sesuai dengan kaidah kebahasaan Pelajaran bahasa Indonesia memiliki peran yang sangat penting bukan hanya untuk membina keterampilan komunikasi melainkan juga untuk kepentingan penguasaan ilmu pengetahuan. Suryaman (2012) menjelaskan bahwa bahasa dalam berkomunikasi digunakan untuk bertukar pikiran, perasaan, pendapat, imajinasi, dan sebagainya sehingga terjadi kegiatan sambutmenyambut. Maksud penjelasan tersebut adalah bahwa kegiatan berbahasa seringkali digunakan dalam berkomunikasi, yaitu oleh sesorang dalam berhubungan dengan yang lainnya sehingga mereka dapat hidup berdampingan. Melalui bahasa manusia belajar berbagai macam pengetahuan yang ada di dunia, oleh karenanya wajarlah jika para filsuf menganggap bahawa bahasa merupakan induk ilmu pengetauan di samping matematika.

Dibia, (2007)menyatakan pembelajaran Bahasa Indonesia tidak akan terlepas dari empat keterampilan berbahasa yaitu menyimak, berbicara, membaca dan menulis. Keempat keterampilan bahasa tersebut sangat penting dan wajib dimiliki oleh peserta didik sebagai sarana atau modal awal untuk berinteraksi dengan orang lain. Agar siswa dapat menggunakan bahasa dalam suatu interaksi, maka ia harus memiliki keterampilan yaitu keterampilan berbahasa. Menurut Mulyati (dalam(Zulaeha, 2016) keterampilan berbahasa bermanfaat dalam melakukan interaksi komunikasi dalam masyarakat. Banyak profesi dalam kehidupan bermasyarakat yang keberhasilannya, antara lain bergantung pada tingkat keterampilan berbahasa yang dimilikinya Keterampilan tersebut digunakan untuk mengomunikasikan pesan. Pesan ini dapat berupa ide, keinginan kemauan, perasaan ataupun interaksi. Salah satu cara yang 
dapat digunakan untuk berinteraksi adalah melalui membaca.(Suryaman, 2012)menjelaskan bahwa permasalahan terbesar dan mendasar di dalam pembelajaran bahasa Indonesia saat ini adalah permasalah berkenaan dengan kemampuan dan kebiasaan membaca. Sejalan dengan pendapat (Olivia, 2008)bahwa kesulitan terletak pada membaca secara lancar dan membaca untuk memahami.

(H.G, 2015)menyatakan bahwa membaca adalah suatu proses yang dilakukan serta dipergunakan oleh pembaca untuk memperoleh pesan yang hendak disampaikan oleh penulis melalui media kata-kata/bahasa tulis. (Yunus, 2016)menyatakan membaca juga dapat dikatakan sebagai proses untuk mendapatkan informasi yang terkandung dalam teks bacaan untuk memperoleh pemahaman atas bacaan tersebut atau sering disebut sebagai membaca pemahaman. Membaca menjadi jembatan bagi siswa yang ingin memiliki keterampilan interaktif dan terpadu. Membaca juga dianggap sebagai keterampilan berbahasa yang mudah oleh sebagian besar siswa, hal ini tidak terjadi pada keterampilan membaca pemahaman siswa. Permasalahan awal yang muncul adalah sulitnya memahami bacaan secara keseluruhan.

Menurut (Dalman, 2013)membaca pemahaman merupakan keterampilan membaca yang berada pada urutan yang lebih tinggi. Dalam membaca pemahaman, pembaca dituntut mampu memahami isi bacaan. Pada tahap membaca pemahaman pembaca tidak lagi dituntut bagaimana melafalkan huruf dengan benar dan merangkaikan setiap bunyi bahasa menjadi bentuk kata, frase, dan kalimat. Tetapi, disini ia dituntut untuk memahami isi bacaan yang dibacanya. Adapun indikator membaca pemahaman menurut (Somadaya, 2011)yaitu memiliki kemampuan menangkap arti kata dan ungkapan yang digunakan penulis, memiliki kemampuan menangkap makna tersurat dan makna tersirat, memiliki kemampuan menentukan ide pokok, gagasan pokok dan gagasan pendukung, dan memiliki kemampuan membuat sebuah simpulan.

Berdasarkan hasil observasi yang dilakukan pada hari sabtu, 19 Oktober 2019 di SD Negeri yang terdapat di Gugus VI Kecamatan Sukasada, Kabupaten Buleleng membuktikan bahwa terdapat beberapa siswa kelas IV SD yang belum bisa membaca, terdapat siswa yang mengalami kesusahan dalam memahami isi bacaan pada materi yang dibaca, ada siswa yang membacanya masih secara terbata-bata, dan guru yang mengajar masih menggunakan metode ceramah serta belum mengetahui model pembelajaran yang sesuai untuk meningkatkan kemampuan membaca siswa.

Kemudian berdasarkan hasil wawancara yang dilakukan dengan guru pada hari Sabtu, 26 Oktober 2019 menyatakan bahwa permasalahan tersebut disebabkan oleh beberapa faktor yaitu: 1) Rasa keingintahuan dari siswa dalam membaca sangat kurang terlihat, hal itu terbukti ketika siswa membaca materi yang diberikan guru, siswa hanya membaca tanpa mengetahui ataupun memahami isi materi yang ia baca. 2) Kurangnya sarana berupa buku bacaan yang ada di sekolah. 3). Kurangnya minat siswa untuk belajar membaca, serta sulitnya memahami isi bacaan pada teks yang dibaca. Selain itu dalam proses pembelajaran siswa hanya sekedar membaca teks tanpa memahami isi dari teks yang mereka baca tersebut dan siswa hanya sekedar mendengarkan apa yang disampaikan oleh guru pada saat menjelaskan materi sehingga konsep atau pengetauhan yang tertanam atau yang siswa dapatkan tidak melekat kuat dalam benak siswa dan kerap kali lupa akan materi yang telah dipelajarinya. Sebagian besar penyajian materi pembelajaran bahasa Indonesia oleh guru menggunakan metode ceramah. Dampak dari permasalahan tersebut adalah siswa akan susah dalam mengikuti proses pembelajaran terutama pelajaran Bahasa Indonesia, yang mana dalam pelajaran bahasa Indonesia siswa dituntut untuk lebih banyak membaca teks.

Hasil pencatatan dokumen terkait rata-rata nilai UTS pada mata pelajaran Bahasa Indonesia siswa kelas IV SD Gugus VI Kecamatan Sukasada Kabupaten Buleleng tahun pelajaran 2019/2020 dipaparkan seperti yang ada pada tabel 1. 
Tabel 1. Rata-rata Nilai UTS Siswa Kelas IV SD di Gugus VI Kecamatan Sukasada Kabupaten Buleleng

\begin{tabular}{|c|c|c|c|c|c|c|c|c|}
\hline \multirow[t]{2}{*}{ No } & \multirow[t]{2}{*}{ Sekolah } & \multirow[t]{2}{*}{$\begin{array}{l}\text { Jumlah } \\
\text { Siswa }\end{array}$} & \multirow[t]{2}{*}{$\mathrm{Kkm}$} & \multirow[t]{2}{*}{$\begin{array}{l}\text { Rata- } \\
\text { Rata }\end{array}$} & \multicolumn{2}{|c|}{$\begin{array}{l}\text { Siswa Yang } \\
\text { Mencapai } \\
\text { Kkm }\end{array}$} & \multicolumn{2}{|c|}{$\begin{array}{c}\text { Siswa Yang } \\
\text { Belum Mencapai } \\
\text { Kkm }\end{array}$} \\
\hline & & & & & Siswa & $\%$ & Siswa & $\%$ \\
\hline 1. & $\begin{array}{l}\text { SD N } 1 \text { PANJI } \\
\text { ANOM }\end{array}$ & 35 & 65 & 60,11 & 14 & $40 \%$ & 21 & $60 \%$ \\
\hline 2. & $\begin{array}{l}\text { SD N } 2 \text { PANJI } \\
\text { ANOM }\end{array}$ & 32 & 66 & 65,47 & 12 & $38 \%$ & 20 & $62 \%$ \\
\hline 3. & $\begin{array}{l}\text { SD N } 3 \text { PANJI } \\
\text { ANOM }\end{array}$ & 21 & 70 & 69,29 & 14 & $67 \%$ & 7 & $33 \%$ \\
\hline 4. & $\begin{array}{l}\text { SD N } 4 \text { PANJI } \\
\text { ANOM }\end{array}$ & 25 & 70 & 71,08 & 18 & $72 \%$ & 7 & $28 \%$ \\
\hline 5. & $\begin{array}{l}\text { SD N } 1 \\
\text { TEGALINGGAH }\end{array}$ & 21 & 61 & 56,20 & 8 & $38 \%$ & 13 & $62 \%$ \\
\hline 6. & $\begin{array}{l}\text { SD N } 2 \\
\text { TEGALINGGAH }\end{array}$ & 32 & 62 & 61,25 & 15 & $47 \%$ & 17 & $53 \%$ \\
\hline 7. & $\begin{array}{l}\text { SD N } 4 \\
\text { TEGALINGGAH }\end{array}$ & 12 & 60 & 59,58 & 6 & $50 \%$ & 6 & $50 \%$ \\
\hline JUN & $\mathrm{LAH}$ & 178 & & & 87 & $49 \%$ & 91 & $51 \%$ \\
\hline
\end{tabular}

(Sumber : wali kelas IV SD Gugus VI Kecamatan Sukasada)

Berdasarkan data pada tabel 1. diketahui terdapat kesenjangan antara harapan dan kenyataan pada muatan pelajaran Bahasa Indonesia khususnya kemampuan membaca pemahaman. Hasil pada tabel 1. terlihat bahwa keberhasilan pencapaian nilai kemampuan membaca pada muatan pelajaran Bahasa Indonesia kelas IV SD Gugus VI Kecamatan Sukasada tergolong rendah dan belum mencapai hasil belajar yang memuaskan. Hal ini dapat terlihat pada tabel di atas menunjukkan nilai rata-rata UTS Bahasa Indonesia siswa yang masih di bawah KKM. (Yudasmini, 2015)Rendahnya hasil belajar bahasa Indonesia dapat dipengaruhi oleh dua faktor, yakni metode pembelajaran yang digunakan dankemampuan membaca. Rendahnya hasil belajar dan kemampuan membaca siswa kemungkinan salah satunya disebabkan dari faktor guru, yaitu pembelajaran bahasa Indonesia yang diterapkan masih cenderung menggunakan pembelajaran konvensional. Pembelajaran yang didominasi metode ceramah, tanya jawab. Metode ceramah belum dapat mengoptimalkan aktivitas siswa. Saat guru mengajukan pertanyaan hanya siswa yang pintar cenderung mendominasi jawaban pertanyaan guru dan siswa yang kurang pintar terkesan pasif.

Berdasarkan permasalahan yang ditemukan, perlu diadakan pembelajaran yang dapat membuat siswa aktif dan senang belajar membaca. Seorang guru harus dapat menciptakan suasana yang menyenangkan sehingga siswa aktif bertanya, mempertanyakan, dan mengemukakan gagasannya. Dalam pembelajaran bahasa Indonesia di SD, guru diarahkan untuk meningkatkan kemampuan siswa dalam membaca dan berkomunikasi dengan bahasa Indonesia baik secara lisan maupun tertulis. Selain meningkatkan kemampuan membaca siswa, pembelajaran bahasa juga untuk meningkatkan kemampuan berpikir, bernalar, dan memperluas wawasan. Guru dalam pembelajaran seharusnya dapat menciptakan pembelajaran yang kreatif dan inovatif sesuai dengan kebutuhan siswa khususnya dalam meningkatkan kemampuan membaca siswanya. Karena kemampuan memahami bacaan akan memengaruhi penyerapan siswa selama proses pembelajaran. Siswa juga akan sulit mengembangkan skil-skil lainnya yang seringkali hanya bisa diperoleh dengan jalan 
membaca. Maka dari itu guru dalam pembelajaran seharusnya dapat menciptakan pembelajaran yang kreatif dan inovatif sesuai dengan kebutuhan siswa khususnya dalam meningkatkan kemampuan membaca siswanya. "Guru dalam proses pembelajaran harus memiliki kompetensi tersendiri guna mencapai harapan yang dicita-citakan dalam melaksanakan pendidikan pada umumnya dan proses belajar mengajar pada khususnya"(Djam'an, 2008)

Keberhasilan pendidikan dalam sebuah lembaga pendidikan tidak hanya ditumpukan pada peserta didik saja tetapi lebih banyak pada seberapa besar guru memberikan solusi cara atau metode pembelajaran yang membuat peserta didik menikmati pelajaran itu serta membuatnya senang. Salah satu model pembelajaran yang dapat digunakan guru sebagai variasi dalam proses pembelajaran adalah model pembelajaran kooperatif. Banyak jenis model pembelajaran kooperatif yang dapat diterapkan dalam pembelajaran bahasa Indonesia, salah satunya adalah model pembelajaran Cooperatif Integrated Reading Composition (CIRC). Cooperatif Integrated Reading Composition (CIRC) dalam pembelajaran menulis bertujuan untuk merancang, mengimplementasikan, dan mengevaluasi pendekatan proses menulis pada pelajaran menulis dan seni berbahasa yang akan banyak memanfaatkan kehadiran teman satu kelas.

Untuk meningkatkan kemampuan tersebut, maka salah satu model yang dapat diterapkan guru dalam pembelajaran bahasa Indonesia adalah model pembelajaran kooperatif CIRC (Cooperative Integrated Reading and Composition). Dengan menerapkan model pembelajaran CIRC dapat memberikan solusi dan suasana baru yang menarik dalam proses pembelajaran sehingga siswa memperoleh konsep baru. (Kurniasih \& Berlin, 2017)berpendapat bahwa model pembelajaran CIRC merupakan model pembelajaran yang lebih cocok dan tepat di aplikasikan pada mata pelajaran Bahasa Indonesia khusus pada materi membaca, menemukan ide pokok, pokok pikiran atau, tema sebuah wacana. Terdapat kelebihan dalam model pembelajaran Cooperatif Integrated Reading Composition (CIRC) yang mendorong peneliti menggunakan model pembelajaran ini dalam melakukan penelitian. Kelebihannya yaitu (a) Model Pembelajaran CIRCsangat tepat untuk meningkatkan siswa dalam menyelesaikan soal pemecahan masalah, (b) dominasi guru dalam pembelajaran berkurang, (c) siswa termotivasi pada hasil secara teliti karena bekerja dalam kelompok, (d) para siswa dapat memahami makna soal dan saling mengecek pekerjaannya, (e) membantu siswa yang lemah, (f) meningkatkan hasil belajar khususnya dalam menyelesaikan soal yang berbentuk pemecahan masalah.

Menurut (Yunus, 2016)pembelajaran yang menggunakan model CIRC membawa konsep pemahaman inovatif sehingga dapat mengoptimalkan hasil belajar bahasa Indonesia. Model pembelajaran CIRC membuat siswa termotivasi pada proses pembelajaran, karena bekerja dalam kelompok. Siswa tidak hanya mengharapkan bantuan dari guru saja tetapi juga mendapat bantuan dari teman sebaya, serta siswa juga dapat termotivasi untuk belajar cepat, akurat, dan dapat mencapai ketuntasan belajar dalam seluruh materi. Model CIRC adalah komposisi terpadu membaca dan menulis secara kooperatif-kelompok (Suyatno, 2009). Pembelajaran bahasa Indonesia di SD memerlukan strategi atau model pembelajaran tertentu agar materi pembelajaran lebih mudah dipahami oleh siswa. Mata pelajaran bahasa Indonesia apabila diajarkan dengan cara yang tepat, maka akan menjadi suatu mata pelajaran yang lebih menarik bagi siswa. Pemilihan sumber belajar yang bervariasi di SD sangat diperlukan, sebab anak-anak usia SD sangat memerlukan ragam sumber belajar. Anak-anak sekolah dasar dalam belajar mempunyai kecenderungan beranjak dari halhal kongkrit (nyata) memandang sesuatu yang dipelajarinya sebagai suatu kebutuhan, terpadu dan melalui suatu proses manipulatif. Berkaitan dengan hal itu, maka penanganan permasalahan secara tepat dan benar sangat diperlukan dalam pengajaran konsep bahasa Indonesia. Salah satunya adalah dengan memilih dan 
menerapkan model pembelajaran yang sesuai dengan materi yang akan dipelajari dalam proses pembelajaran. Pembelajaran kooperatif tipe CIRC (Cooperative Integrated Reading and Composition) adalah sebuah program komprehensif atau luas dan lengkap untuk pengajaran membaca dan menulis untuk kelas-kelas tinggi sekolah dasar. (Yudasmini, 2015) Pengembangan model pembelajaran CIRC (Cooperatif Integrated Reading and Composition) yang secara stimulan difokuskan pada kurikulum dan metode-metode pembelajaran merupakan sebuah upaya untuk memperkenalkan teknik terbaru latihan-latihan kurikulum yang berasal dari penelitian dasar mengenai pengajaran praktis pelajaran membaca dan menulis.

Model pembelajaran Cooperatif Integrated Reading Composition (CIRC) adalah salah satu model kooperatif yang komprehensif untuk mengajarkan pembelajaran membaca, menulis, dan seni berbahasa (Suprijono, 2011). Tujuan utama dari model ini adalah menggunakan tim-tim kooperatif untuk membantu peserta didik mempelajari kemampuan memahami bacaan yang dapat diaplikasikan secara luas. Peserta didik dalam model Cooperative Integrated Reading and Composition juga membuat penjelasan terhadap prediksi mengenai bagaimana masalah-masalah akan diatasi dan merangkum unsur-unsur utama dari cerita kepada satu sama lain yang diharapkan dapat meningkatkan pemahaman dalam membaca. Selain itu, tujuan utama model Cooperative Integrated Reading and Composition adalah untuk merancang, mengimplementasikan, dan mengevaluasi pendekatan proses pada pembelajaran menulis dan seni berbahasa yang banyak memanfaatkan kehadiran teman satu kelas.

Dalam model pembelajaran Cooperatif Integrated Reading Composition ini peserta didik bertanggung jawab terhadap tugas kelompok. Setiap anggota kelompok saling mengeluarkan ide untuk memahami suatu konsep dan menyelesaikan tugas dalam pembelajaran materi menyusun teks cerita pendek, sehingga terbentuk sebuah pemahaman yang sama. Selain itu, proses pembelajaran model Cooperative Integrated Reading and Composition ini juga mendidik peserta didik untuk berinteraksi dengan lingkungan. Tujuan dari model pembelajaran Cooperative Integrated Reading and Composition ini adalah meningkatkan cara berpikir kritis, kreatif, dan menumbuhkan sikap sosial peserta didik dengan peserta didik dalam satu kelompoknya maupun dengan kelompok lain.

Pendekatan pembelajaran kooperatif mengikuti penemuan pada penelitian sebelumnya, menekankan tujuan-tujuan kelompok dan tanggung jawab individual Penelitian yang sebelumnya dilakukan oleh (Marpuah, Rahayuningsih, \& Sukaesih, 2015)yang mendapatkan hasil bahwa model pembelajaran CIRC dengan mind mapping berpengaruh terhadap aktivitas dan hasil belajar siswa kelas X SMA Negeri 1 Wirosari. Peningkatan aktivitas dan hasil belajar siswa kelas eksperimen lebih besar dibandingkan kelas kontrol. Dan penelitian sejalan juga dilakukan oleh Ilham (2016) mendaptkan hasil bahwa terdapat pengaruh yang signifikan penggunaan model pembelajaran kooperatif tipe CIRC bermuatan nilai karakter terhadap kemampuan menulis cerpen siswa kelas VII SMPN 5 Muara Bungo

Di dalam pembelajaran kooperatif terdapat bermacam-macam model pembelajaran. Salah satunya adalah model pembelajaran CIRC yang dirancang khusus untuk pembelajaran membaca dan menulis, untuk membedakan model pembelajaran CIRC dengan model pembelajaran kooperatif lainnya dapat dilihat dari ciri-cirinya. Berikut ciri-ciri dari CIRC menurut(Sumarni, 2008), yaitu: (1) adanya suatu tujuan kelompok; (2) adanya tanggung jawab tiap individu; (3) tidak adanya tugas khusus; (4) tiap anggota dalam satu kelompok memiliki kesempatan yang sama untuk sukses; (5) dibutuhkan penyesuaian diri tiap anggota kelompok. Pembelajaran CIRC (Cooperative Integrated Reading Composition) merupakan pembelajaran yang muncul dari konsep bahwa siswa akan lebih mudah menemukan dan memahami konsep yang sulit jika mereka saling berdiskusi dengan temannya. Hal tersebut menunjukkan bahwa aktivitas siswa dalam bentuk diskusi sangat menentukan 
keberhasilan siswa dalam memahami segala konsep dalam pembelajaran. Dalam bentuk kelompok kecil siswa saling membantu memecahkan masalah yang ada. Pemahaman siswa akan menjadi kuat karena siswa sendiri yang menemukannya melalui diskusi.

\section{Metode}

Penelitian ini dilaksanakan pada siswa kelas IV SD Gugus VI Kecamatan Sukasada tahun Pelajaran 2019/2020. Dalam penelitian ini, kegiatan penelitian menerapkan sebuah konsep model pembelajaran Cooperatif Integrated Reading Composition (CIRC) untuk mengetahui seberapa kemampuan membaca pemahaman siswa. Rancangan penelitian pada proposal ini adalah menggunakan penelitian Eksperimen, mengingat tidak semua variabel (gejala yang muncul) dan kondisi eksperimen dapat diatur dan dikontrol secara ketat, maka penelitian ini dikategorikan sebagai penelitian pra eksperimental.

Rancangan penelitian yang digunakan adalah one shot-case study. "Desain ini adalah desain yang paling sederhana. Perlakuan diberikan terhadap suatu kelompok, selanjutnya dilakukan pengambilan data" (Dantes, 2017). Dalam rancangan ini satu kelompok dikenakan perlaukan tertentu (variabel bebas) dalam penelitian ini variabel bebasnya adalah model pembelajaran $C I R C$, kemudian dilakukan pengukuran terhadap variabel terikatnya, dalam penelitian ini variabel terikatnya adalah kemampuan membaca pemahaman siswa SD kelas IV. Prosedur yang ditempuh dalam penelitian ini terdiri dari tiga tahapan, yaitu tahap persiapan, tahap pelaksanaan, dan tahap akhir penelitian.

Populasi dalam penelitian ini adalah siswa kelas IV di Gugus VI Kecamatan Sukasada, Kabupaten Buleleng yang berjumlah 178 siswa. Gugus VI Kecamatan Sukasada, Kabupaten Buleleng terdiri dari tujuh sekolah. sampel yang digunakan ialah siswa kelas IV SD N 1 Panji Anom yang berjumlah 35 siswa. Adapun teknik pengambilan sampel ini dilakukan dengan cara (1) menulis nama kelas yang menjadi populasi pada kertas misalnya kelas IV SD $\mathrm{N} 1$ Panji Anom, Kelas IV SD N 1 Tegalinggah, dll sampai semua nama kelas IV yang menjadi populasi tersebut ditulis, (2) kertas tersebut kemudian dilipat atau diremas hingga tulisannya tidak terlihat, (3) ambil satu kertas tersebut untuk memilih sampel yang akan digunakan sebagai kelas eksperimen, (4) akhirnya keluarlah nama kelas IV SD N 1 Panji Anom sebagai kelas eksperimennya.

Terdapat dua variabel dalam penelitian ini, yaitu variabel bebas dan variabel terikat. Dalam penelitian ini yang menjadi variabel bebas adalah model pembelajaran Cooperatif Integrated Reading Composition (CIRC) yang dikenakan pada kelompok eksperimen. Sedangkan variabel terikat dalam penelitian ini adalah kemampuan membaca pemahaman siswa kelas IV SD.

Dalam penelitian ini, metode pengumpulan data yang digunakan adalah metode tes. Metode tes dalam penelitian ini digunakan untuk mendapatkan data mengenai kemampuan membaca pemahaman siswa. Instrumen pengumpulan data dalam penelitian ini adalah tes objektf. Bentuk tes pilihan ganda yang digunakan dalam penelitian ini adalah pilihan ganda biasa. Tes pilihan ganda biasa terdiri 4 alternatif jawaban ( $a, b, c$, dan d). setiap item diberikan skor 1 bila siswa menjawab dengan benar (jawaban disesuaikan dengan kunci jawaban) dan skor 0 bila siswa menjawab salah.

Untuk mengetahui instrumen yang dibuat tersebut sudah layak atau tidak, maka instrumen tersebut perlu di uji cobakan terlebih dahulu. Yang dapat diuji cobakan pada suatu instrumen yaitu tingkat validitas, reliabilitas, tingkat kesukaran, dan daya beda tes. Kisi-kisi tes sangat diperlukan dalam penyusunan instrumen. Kisi-kisi yang digunakan sebagai acuan untuk menyusun instrumen pengumpulan data dalam penelitian ini menggunakan soal objektif. Kisi-kisi instrumen untuk mengukur variabel 
kemampuan membaca pemahaman siswa pada pembelajaran Bahasa Indonesia secara lengkap dapat dilihat pada tabel 2.

Tabel 2. Kisi-kisi Instrumen Tes Kemampuan Membaca Pemahaman

\section{Kompetensi Indiktor \\ Dasar}

3.7

Menggali

pengetahuan

baru

terdapat pada

teks

\subsection{1}

bacaan.
Mengidentifikasi arti

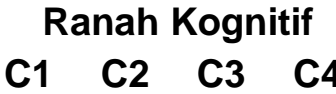

Nomor Soal

$1,2,3,4,5,6,7,8$

kata dan ungkapan

yang ada pada teks

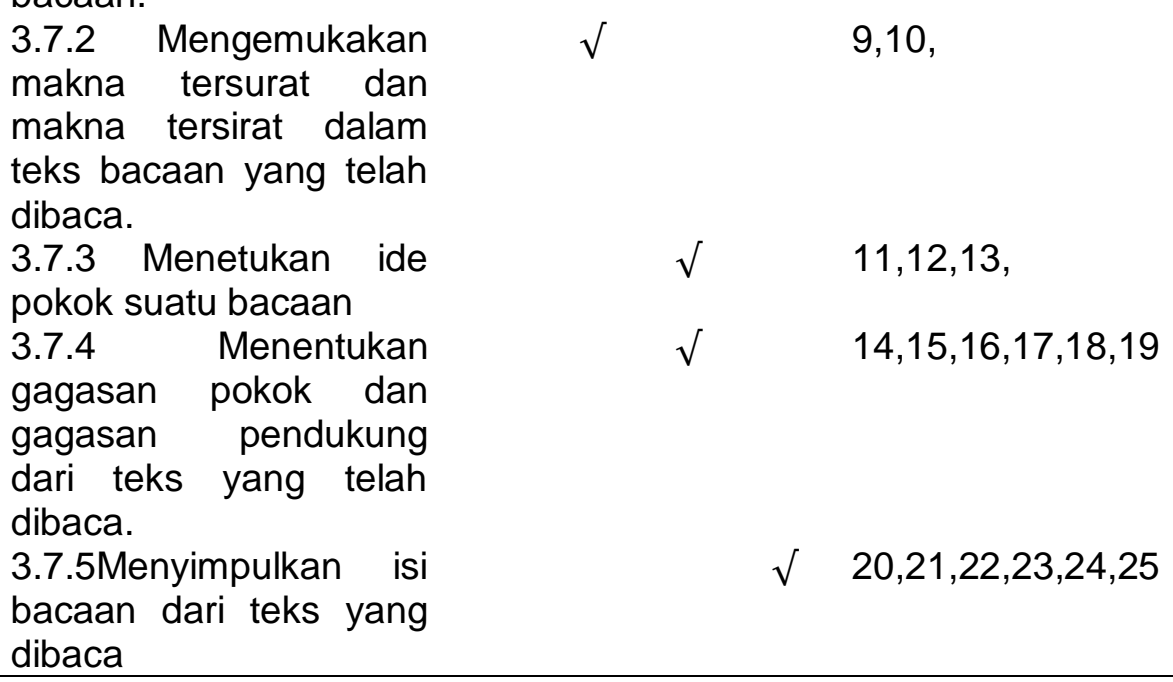

Pengujian instrumen dilakukan untuk menguji kelayakan instrument penelitian dalam proses pengambilan data. Instrumen penelitian harus melewati tahapan uji valiidtas isi, uji validitas butir, uji taraf kesukaran, uji daya beda, dan uji reliabilitas sebelum digunakan. Pada penelitian ini menggunakan uji t bruning untuk menganlisis data kemampuan membaca pemahaman. pada saat hasil penelitian telah didapatkan, selanjutnya dilakukan uji prasyarat dan uji hipotesis. Uji prasyarat merupakan bagian dari statistic inferensial. Statistik inferensial terdiri dari uji normalitas dan uji homogenitas. Data yang diperoleh dianalisis menggunakan uji prasyarat, uji t Bruning menggunakan bantuan program SPSS 25.0 for Windows.

\section{Hasil dan Pembahasan}

Dari hasil analisis data yang dilakukan terhadap tes kemampuan membaca pemahaman, diperoleh hasil perhitungan uji prasyarat dengan bantuan program SPSS 25.0 for Windowsyang tersaji pada tabel. Uji prasyarat dilakukan untuk menguji normalitas data, homogenitas varians yang sudah diperoleh saat melaksankan posttest. Berdasarkan uji normalitas data, diperoleh nilai signifikansi Kolmogrov Smirnov lebih besar dari 0,05. Dengan demikian, semua sebaran data dapat diakatakan berdistribusi normal. Hasil uji normalitas dapat dilihat pada tabel 3. 
Tabel 3. Hasil Uji Normalitas Data Kemampuan Membaca Pemahaman Siswa Kelas IV SD

\begin{tabular}{cccc}
\hline & \multicolumn{3}{c}{ Tests Of Normality } \\
& Kolmogrov-smirnov a & \\
& Statistic & Df & Sig. \\
Kemampuan & 0.133 & 35 & 0.120 \\
Membaca & & & \\
Pemahaman & & & \\
\hline
\end{tabular}

Berdasarkan tabel diatas menunjukkan bahwa nilai signifikansi (Sig.) yang diperoleh setelah dilakukan uji analisis data memperoleh hasil nilai signifikansi ( $p$ ) pada uji kolmogorov-smirnov adalah 0.120. Karena nilai signifikansi $0.120>0.05$ ( $p>0.05$ ), maka sebagaimana dasar pengambilan keputusan dalam uji normalitas diatas, dapat disimpulkan bahwa varians data keampuan membaca pemahaman pada siswa kelas IV SD dapat dikatakan berdistribusi normal.

Uji homogenitas varians dilakukan untuk menguji tingkat kehomogenan secara dua pihak. Uji homogenitas varians pada penelitian ini menggunakan program SPSS 25.0 for Windows. Pengambilan keputusan dilakukan dengan membandingkan nilai signifikansi pada Based On Mean (rata-rata) lebih besar dari nilai signifikansi 0,05 maka data tersebut memiliki varians yang homogen. Adapun hasil uji homogenitas varians dapat dilihat pada tabel berikut.

Tabel 4. Uji Homogenitas Varians Kemampuan Membaca Pemahaman Test Of Homogenity of Variances

\begin{tabular}{|c|c|c|c|c|c|}
\hline & & $\begin{array}{l}\text { Levene } \\
\text { Statistics }\end{array}$ & Df1 & Df2 & Sig. \\
\hline $\begin{array}{l}\text { Kemampuan } \\
\text { Membaca }\end{array}$ & Based On Mean & 1.154 & 1 & 33 & 0.291 \\
\hline \multirow{3}{*}{ Pemahaman } & Based On Median & 0.196 & 1 & 33 & 0.346 \\
\hline & $\begin{array}{l}\text { Based On Median and } \\
\text { with adjusted df }\end{array}$ & 0.196 & 1 & 32.994 & 0.346 \\
\hline & $\begin{array}{l}\text { Based On Trimmed } \\
\text { Mean }\end{array}$ & 1.178 & 1 & 33 & 0.286 \\
\hline
\end{tabular}

Berdasarkan tabel diatas, dapat dilihat bahwa signifikansi pada based on mean sebesar 0,291. Hal ini berarti nilai signifikansi pada based on mean lebih besar dari 0,05 , sehingga dapat disimpulkan data hasil penelitian adalah homogen.

Berdasarkan uji prasyarat analisis data yang telah dilakukan, diperoleh data kemampuan membaca pemahaman siswa normal dan homogen. Kemudian akan dilaksanakan pengujian hipotesis penelitian. Pengujian hipotesis penelitian dilakukan dengan bantuan program SPSS 25.0 for Windows. Namun sebelum melakukan uji hipotesis, adapun hipotesis dalam penelitian ini dijabarkan sebagai beriikut.

$\mathrm{Ho}=$ Tidak Terdapat pengaruh yang signifikan model pembelajaran $C I R C$ terhadap kemampuan membaca pemahaman siswa kelas IV SD.

$\mathrm{H} 1$ = Terdapat pengaruh yang signifikan model pembelajaran $C I R C$ terhadap kemampuan membaca pemahaman siswa kelas IV SD.

Kriteria untuk pengujian hipotesis adalah Ho diterima jika nilai signifikansi lebih besar dari 0,05 dan Ho ditolak jika nilai signifikansi lebih kecil dari 0,05. Adapun 
rekapitulasi uji hipotesis menggunakan bantuan program SPSS 25.0 for Windows disajikan pada tabel 5.

Tabel 5. Rekapitulasi Hasil Uji Hipotesis One-Sample Test

\begin{tabular}{|c|c|c|c|c|c|c|}
\hline & \multirow{2}{*}{\multicolumn{6}{|c|}{ Test Value $=65$}} \\
\hline & & & & & & \\
\hline & \multirow[t]{2}{*}{$\mathrm{T}$} & \multirow[t]{2}{*}{ Df } & \multirow[t]{2}{*}{$\begin{array}{l}\text { Sig. (2- } \\
\text { tailed) }\end{array}$} & \multirow[t]{2}{*}{$\begin{array}{c}\text { Mean } \\
\text { Difference }\end{array}$} & \multicolumn{2}{|c|}{$\begin{array}{c}\text { 95\% Confidence } \\
\text { Interval of the } \\
\text { Difference }\end{array}$} \\
\hline & & & & & Lower & Upper \\
\hline $\begin{array}{l}\text { Kemampuan } \\
\text { Membaca } \\
\text { Pemahaman }\end{array}$ & $\begin{array}{r}11.3 \\
36\end{array}$ & 34 & .000 & 17.28571 & 14.1867 & 20.3847 \\
\hline
\end{tabular}

Berdasarkan hasil uji hipotesis diatas, maka diperoleh nilai t sebesar 11.336 dengan taraf signifikansi sebesar 0,000. Selanjutnya, nilai tersebut dibandingkan dengan 0,05. Itu artinya 0,000 lebih kecil dari 0,05 sehingga Ho ditolak dan $\mathrm{H} 1$ diterima. Jadi, dapat disimpulkan bahwa terdapat pengaruh yang signifikan model pembelajaran CIRC terhadap kemampuan membaca pemahaman siswa kelas IV SD.Berdasarkan hasil uji analisis yang telah dilakukan, pada penelitian ini menunjukkan terdapat pengaruh model pembelajaran CIRC terhadap kemampuan membaca pemahaman siswa kelas IV SD.

Bisa membaca sangatlah penting bagi setiap orang, hal itu dikarenakan banyak manfaat yang diperoleh dari membaca. Dengan membaca siswa dapat memperluas cakrawala ilmu pengetahuan, menambah informasi bagi diri sendiri, meningkatkan pengetahuan serta menambah ide. Jadi jelas pengaruh bacaan sangat besar terhadap peningkatan cara berfikir seorang siswa. Menurut Gray \& Rogers (dalam Zaif: 2011 ) menyebutkan beberapa manfaat membaca, antara lain: 1. meningkatkan pengembangan diri siswa. Dengan membaca siswa dapat meningkatkan ilmu pengetahuan, sehingga daya nalarnya berkembang dan berpandangan luas yang akan bermanfaat bagi dirinya maupun orang lain. 2. memenuhi tuntutan intelektual. Dengan membaca buku maupun sumber-sumber bacaan lain seperti surat kabar maupun berita dan artikel-artikel di internet, pengetahuan bertambah dan perbendaharaan kata-kata meningkat, melatih imajinasi dan daya pikir sehingga terpenuhi kepuasan intelektual. 3. memenuhi kepentingan hidup. Dengan membaca siswa akan memperoleh pengetahuan praktis yang berguna dalam kehidupan mereka sehari-hari. 4. Meningkatkan minat siswa terhadap suatu bidang Mengetahui hal-hal yang aktual, dengan membaca siswa dapat mengetahui peristiwa-peristiwa yang terjadi di lingkungan sekitar maupun di seluruh dunia yang mungkin berhubungan materi pelajaran, sehingga siswa dapat menerapkan pada kehidupan nyata.

Pada dasarnya kegiatan membaca bertujuan untuk mencari dan memperoleh pesan atau memahami makna melalui bacaan. Tujuan membaca tersebut akan berpengaruh kepada jenis bacaan yang dipilih, misalnya fiksi atau nonfiksi (Dalman, 2013). Dalam hal ini, teks bacaan (fiksi atau non fiksi) yang digunakan untuk membaca perlu disesuaikan dengan tujuan yang ingin dicapai. Adapun tujuan pada penelitian ini adalah untuk meningkatkan kemampuan membaca pemahaman siswa kelas IV SD.

Menurut (Dalman, 2013)Membaca pemahaman atau membaca lanjut merupakan keterampilan membaca yang berada pada urutan yang lebih tinggi. Dalam membaca pemahaman, pembaca dituntut mampu memahami isi bacaan. Oleh sebab itu, setelah membaca teks, si pembaca dapat menyampaikan hasil pemahaman membacanya dengan cara membuat rangkuman isi bacaan dengan menggunakan bahasa sendiri dan menyampaikannya baik secara lisan maupun tulisan. Kemampuan membaca pemahaman harus dimiliki oleh siswa yang mempelajari beberapa kompetensi dasar 
dalam satu pembelajaran. Jika tidak memiliki kemampuan membaca maka siswa tidak akan dapat memahami materi pembelajaran tersebut. Berkaitan dengan kurikulum yang diterapkan saat ini adalah kurikulum 2013. Tujuan kurikulum 2013 mentuntut siswa untuk berpikir lebih kreatif, inovatif, cepat dan tanggap, serta melatih siswa untuk menumbuhkan keberanian diri dalam dirinya.

Pada kurikulum 2013 proses pembelajaran berlangsung menggunakan pembelajaran tematik. Untuk mempelajari tema atau sub-sub tema dalam satu pembelajaran, siswa perlu memiliki kemampuan membaca pemahaman yang tinggi. Apabila siswa tidak memiliki kemampuan membaca maka materi pembelajaran tidak akan selesai dan siswa itu tidak akan mengerti apa yang ia pelajari. Menurut Tampubolon (1987) menyatakan bahwa membaca pemahaman merupakan suatu kegiatan membaca untuk membina daya nalar. Membaca dalam pembinaan daya nalar merupakan kegiatan membaca yang dilakukan seseorang untuk memahami suatu makna yang tersirat pada hal tertulis, oleh sebab itu untuk memahami suatu makna seseorang harus melatih daya nalar agar dapat menangkap makna yang tersirat pada hal tertulis.

Sejalan dengan pendapat tersebut, (Somadaya, 2011)menyatakan membaca pemahaman adalah suatu kegiatan atau aktivitas yang dilakukan oleh pembaca untuk menghubungkan informasi baru dengan informasi lama dengan maksud untuk mendapatkan pengetahuan baru. Di samping menghubungkan informasi dan mendapat pengetahuan baru, aktivitas yang dilakukan oleh pembaca dalam memahami bahan bacaan dapat diklasifikasi menjadi pemahaman literal, pemahaman interpretasi, pemahaman kritis, dan pemahaman kreatif.

Model pembelajaran Cooperatif Integrated Reading Composition (CIRC) sangat cocok diterapkan pada saat proses pembelajaran untuk meningkatkan minat belajar siswa, menumbuhkan semangat belajar siswa, mendorong siswa agar dapat berfikir kritis, meningkatkan efisiensi dan efektivitas belajar siswa, dan bisa untuk mengaktifkan interaksi siswa di dalam kelas. Hal ini dikarenakan dalam penerapan model pembelajaran $C I R C$ ini dapat memberikan suatu pembelajaran yang baru. Dari awalnya siswa kurang aktif dalam bertanya maupun menjawab pertanyaan sekarang menjadi lebih aktif di dalam kelas dan suasana kelas lebih terasa hidup karena terjalin interaksi antara individu dengan individu, individu dengan kelompok, dan kelompok dengan kelompok. Hal itu dapat dilihat saat pengimplementasian sintaks dari model pembelajaran CIRC. Adapun sintaks model pembelajaran CIRC menurut(Hasanah \& Pratiwi, 2016) yaitu (1) Fase Orientsi, (2) Fase Organisasi, (3) Fase Pengenalan konsep, (4) fase publikasi, (5) fase Penguatan dan refleksi. Dari kelima fase tersebut yang paling menunjukkan siswa aktif adalah saat fase Pengenalan Konsep. Pada fase ini guru memberikan kesempatan kepada siswa untuk membaca teks bacaan yang telah disediakan guru ataupun teks bacaan yang ada pada buku siswa. Hal itu bertujuan agar siswa menemukan pengetahuan baru dari apa yang ia baca dan bisa mendiskusikannya dalam kelompok tentang pengetahuan-pengetahuan apa yang ditemukan oleh masing-masing siswa dalam kelompok tersebut. Sehingga, interaksi antar anggota kelompok akan terjalin dengan baik begitu pula interaksi dengan antar kelompok dalam kelas tersebut.

Shoimin (2014:51) menekankan model pembelajaran CIRC menekankan pada pelajaran Bahasa Indonesia yang mencakup materi membaca, menulis, menentukan ide pokok, pokok pikiran, menentukan kata sulit serta menemukan arti dari kata tersebut sendiri, menentukan makna tersurat dan makna tersirat, dan juga menentukan pokok pikiran dari suatu bacaan.

Dilihat dari deskripsi hasil penelitian bahwa kemampuan membaca pemahaman siswa dengan menerapkan model pembelajaran Cooperatif Integrated Reading Compositon (CIRC) dapat dikatakan proses pembelajaran siswa di dalam kelas menjadi lebih baik dengan adanya perubahan yang lebih signifikan dibandingkan 
sebelum menggunakan model pembelajaran CIRC saat poses pembelajaran. Karena model pembelajaran ini menurut(Kurniasih \& Berlin, 2017) model pembelajaran CIRC merupakan model pembelajaran yang lebih cocok dan tepat di aplikasikan pada mata pelajaran Bahasa Indonesia khusus pada materi membaca, menemukan ide pokok, pokok pikiran atau, tema sebuah wacana. Menurut Shoimin (2014:51) menyatakan bahwa "model pembelajaran $C I R C$ adalah model pembelajaran khusus mata pelajaran bahasa dalam rangka membaca, dan menemukn ide pokok, pokok pikiran, atau tema sebuah wacana". Pembelajran kooperatif tipe CIRC dari segi bahasa dapat dikatakan sebagai suatu model pembelajaran kooperatif yang mengintegrasikan suatu bacaan secara menyeluruh kemudian mengomposisikannya menjadi bagian-bagian yang penting. Sejalan dengan pendapat tersebut Slavin (2015) menyatakan model pembelajaran Cooperatif Integrated Reading and Composition (CIRC) sebuah program yang komprehensif untuk mengajari pelajaran membaca, menulis, dan seni berbahasa para kelas yang lebih tinggi di SD.

Hasil penelitian tentang pengaruh model pembelajaran CIRC terhadap kemampuan membaca pemahaman siswa sejalan dengan penelitian yang dilakukan oleh(Ketut, Tristiantari, \& Sumantri, 2016) yang menyatakan bahwa terdapat beberapa temuan pada penelitian ini, yaitu: pertama rata-rata keterampilan membaca siswa yang pada siklus I sebesar 67, pada siklus II peningkat mencapai 76; kedua rata-rata keterampilan menulis siswa yang pada siklus I sebesar 69, pada siklus II peningkat mencapai 79; ketiga, pada siklus 1 skor keterampilan membaca siswa dengan kategori "baik" dan "sangat baik" hanya mencapai $57,1 \%$, pada siklus II meningkat menjadi $92,9 \%$ dan keempat pada siklus I, keterampilan menulis siswa dengan kategori "baik" dan "sangat baik" hanya $64,3 \%$, pada siklus II meningkat secara signifikan mencapai $92,9 \%$. Berdasarkan temuan-temuan yang dipaparkan sebelumnya, dapat disimpulkan bahwa penerapan pembelajaran CIRC mampu meningkatkan keterampilan membaca dan menulis siswa kelas IV SD N 3 Kampung Anyar tahun pelajaran 2016/2017. Penelitian sejalan juga dilakukan oleh (Sudiarni \& Sumantri, 2019)mendapatkan hasil bahwa terdapat perbedaan yang signifikan keterampilan membaca pemahaman antara siswa yang dibelajarkan dengan menggunakan model pembelajaran (CIRC) berbantuan penilaian portofolio dan siswa yang dibelajarkan tidak menggunakan model pembelajaran Cooperative Integrated Reading and Composition (CIRC) berbantuan penilaian portopolio pada kelas V di SD Gugus XV Kecamatan Buleleng Tahun Pelajaran 2017/2018.

Penelitian yang dilakukan oleh (Utami, Darsana, \& Suadnyana, 2014)mendapat hasil bahwa terdapat perbedaan yang signifikan hasil belajar IPA antara siswa yang mengikuti model Pembelajaran CIRC dengan siswa yang mengikuti pembelajaran konvensional pada siswa kelas V di SD 4 Tuban tahun pelajaran 2013/2014. (Pt, Setiawati, Arini, \& Suarni, 2017)juga melakukan penelitian yang sama. Hasil penelitiannya menyatakan bahwa kemampuan membaca intensif siswa pada kelas kontrol dengan rata-rata skor $80 \%$ berada pada katagori baik. Kemampuan membaca intensif siswa pada kelompok eksperimen dengan rata-rata skor 90,20\% berada pada katagori sangat baik. Hal ini menunjukkan adanya perbedaan yang signifikan kemampuan membaca intensif antara kelompok siswa yang dibelajarkan dengan model pembelajaran CIRC berbasis tulisan eksposisi dan kelompok siswa yang dibelajarkan dengan model pembelajaran konvensional pada siswa kelas IV di SD Gugus III Kecamatan Banjarangkan, Kabupaten Klungkung Tahun Pelajaran 2016/2017. Penelitian yang dilakukan oleh (Habibi, Setyorini, \& Purworejo, 2018)menyatakan terdapat pengaruh positif penggunaan model pembelajaran CIRC terhadap hasil menulis teks negosiasi siswa. Nilai rata-rata menulis teks negosiasi siswa kelompok eksperimen meningkat yaitu dari 64,10 menjadi 86,3.

Penelitian sejalan juga dilakukan oleh(Syaputri, 2019.) mendapatkan hasil bahwa terdapat pengaruh hasil belajar siswa yang diajarkan dengan model pembelajaran 
CIRC dengan menggunakan Peta Konsep pada materi Jaringan Tumbuhan Di Kelas XI IPA SMA Muhammadiyah 1 Medan T.P. 2017/2018. Selain itu penelitian yang dilakukan oleh (Nyoman, Sawitri, Suniasih, \& Sujana, 2018)menyatakan bahwa terdapat pengaruh model pembelajaran cooperative integrated reading and composition (CIRC) berbasis karakter terhadap kompetensi pengetahuan IPS siswa kelas IV SDN Gugus Pattimura Denpasar Selatan tahun pelajaran 2017/2018.

Dengan demikian dapat diketahui persamaan penelitian-penelitian sebelumnya dengan penelitian yang diteliti adalah sama-sama membahas tentang menggunakan model pembelajaran Cooperatif Integrated Reading Composition (CIRC). Dari hasil penelitian sebelumnya adanya perbedaan sebelum dan sudah menerapkan model pembelajaran Cooperatif Integrated Reading Composition (CIRC) dengan hasil belajar siswa. Sedangkan perbedaan dengan penelitian lain adalah penelitian yang diteliti ini membahas mengenai ada atau tidaknya pengaruh model pembelajaran pembelajaran Cooperatif Integrated Reading Composition (CIRC) terhadap kemampuan membaca pemahaman siswa, dan terdapat pada tempat, waktu, desain penelitian serta populasi yang digunakan. Maka, dapat dikatakan bahwa model pembelajaran pembelajaran Cooperatif Integrated Reading Composition (CIRC) dapat berpengaruh baik terhadap peningkatan kemampuan membaca pemahaman siswa.

Penelitian yang serupa juga dilakukan oleh Rati dan Rediani (2018), Hasil penelitiannya menunjukkan bahwa secara simultan terdapat perbedaan yang signifikan minat baca dan hasil belajaran antara mahasiswa yang mengikuti model pembelajaran CIRC berbantuan Notes dan mahasiswa yang tidak mengikuti model pembelajaran CIRC berbantuan Notes pada mata kuliah Belajar dan Pembelajaran

Dengan demikian, maka model pembelajaran Cooperatif Integrated Reading Composition (CIRC) terhadap kemampuan membaca siswa kelas IV SD N 1 Panji Anom mengalami perubahan yang signifikan kearah positif. Hal itu dibuktikan dengan perlakuan selama 12 kali pertemuan dan 1 kali post test, dan hasil posttes berdasarkan indikator kemampuan membaca pemahaman menunjukkan hasil bahwa kemampuan membaca pemahaman siswa dikatakan meningkat.

\section{Simpulan}

Berdasarkan hasil pengujian dan pembahasan, maka dapat disimpulkan bahwa terdapat pengaruh yang signifikan model pembelajaran Cooperatif Integrated Reading Composition (CIRC) terhadap kemampuan membaca pemahaman siswa kelas IV SD. Berdasarkan pengujian hipotesis menunjukkan bahwa nilai signifikansi sebesear 0,000 hal ini berarti nilai signifikansi $<0,05$ yang berarti Ho ditolak dan $\mathrm{H} 1$ diterima. Sehingga dapat disimpulkan bahwa terdpat pengaruh yang signifikan model pembelajaran Cooperatif Integrated Reading Composition (CIRC) terhadap kemampuan membaca pemahaman siswa kelas IV SD.Adapun saran yang dapat disampaikan berdasarkan penelitian yang telah dilakukan adalah sebagai berikut. (1) Saran yang dapat diberikan kepada siswa SD yaitu agar lebih fokus dan aktif dalam proses pembelajaran agar mampu mengembangkan pemikirannya guna memecahkan permasalahan yang ada serta mampu menemukan fakta, konsep dan pengetahuannya sendiri. (2) untuk Guru SD disarankan untuk lebih mengkreasikan pembelajaran dengan menerapkan model pembelajaran yang inovatif, salah satunya adalah model pembelajaran Cooperatif Integrated Reading Composition (CIRC) untuk dapat meningkatkan kemampuan membaca pemahaman siswa, sebab telah terbukti pada penelitian ini bahwa terdapat perbedaan hasil belajar siswa yang signifikan antara siswa yang dibelajarkan dengan model pembelajaran CIRC sebelum diterapkan dan sesudah diterapkannya model pembelajaran ini. (3) untuk Kepala sekolah hendaknya mengontrol dan mampu mengambil tindakan dalam upaya meningkatkan kualitas pembelajaran melalui pengarahan kepada guru-guru untuk melakukan pembelajaran yang bervariasi dengan menggunakan model atau pendekatan pembelajaran inovatif, salah satunya dengan 
menggunakan model pembelajaran Cooperatif Integrated Reading Composition $(C I R C)$. (4) untuk Peneliti lain yang berminat untuk mengadakan penelitian lebih lanjut tentang model pembelajaran Cooperatif Integrated Reading Composition (CIRC) dalam bidang kemampuan membaca maupun bidang ilmu lainnya yang sesuai agar memperhatikan kendala-kendala yang di alami dalam penelitian ini sebagai bahan pertimbangan untuk perbaikan dan penyempurnaan penelitian yang akan dilaksanakan.

\section{Daftar Pustaka}

Dalman. (2013). Keterampilan Membaca. In Keterampilan Membaca (p. 87).

Dantes, N. (2017). Desain Eksperimen dan Analisis Data. In Desain Eksperimen dan Analisis Data (p. 61).

Dibia, I. K. (2007). Pendidikan Bahasa Indonesia 2. In Pendidikan Bahasa Indonesia 2 (p. 1).

Djam'an, S. (2008). Profesi Keguruan. In Profesi Keguruan.

H.G, T. (2015). Membaca Sebagai Suatu Keterampilan Berbahasa. In Membaca Sebagai Suatu Keterampilan Berbahasa (p. 7).

Habibi, M. A., Setyorini, N., \& Purworejo, U. M. (2018). Pengaruh model pembelajaran circ terhdap kemampuan menulis teks negosiasi pada siswa kelas X SMAN 1 Buluspesantren T.A 2017/2018, 6(55), 684-692.

Hasanah, M., \& Pratiwi, Y. (2016). Integrated Reading And Composition ( CIRC ) Bermuatan Nilai Karakter terhadap Kemampuan Menulis Cerpen Siswa Kelas, 4(3), 121-131.

Ketut, N., Tristiantari, D., \& Sumantri, I. M. (2016). Model pembelajaran cooperatif integrated reading composition berpola lesson study meningkatkan keterampilan membaca dan menulis. Jurnal Pendidikan Indonesia, 5(2), 203-211. https://doi.org/http://dx.doi.org/10.23887/jpi/undiksha.v5i2.8493

Kuis, K. B. (2019). Pengaruh model circ terhadap kemampuan membaca pemahaman siswa kelas V SDN 104231 desa sugiharjo kecamatan batang kuis T.A 2018/2019.

Kurniasih, I., \& Berlin, S. (2017). Ragam pengembangan Model Pembelajaran. In Ragam pengembangan Model Pembelajaran (p. 77).

Marpuah, S., Rahayuningsih, M., \& Sukaesih, S. (2015). Efektivitas model pembelajaran cooperative integrated reading composition (CIRC) dengan mind mapping. Unnes Journal of Biology, 4(3), 244-250.

Nyoman, N., Sawitri, R., Suniasih, N. W., \& Sujana, I. W. (2018). Pengaruh Model Pembelajaran CIRC Kompetensi Pengetahuan IPS Berbasis Karakter terhadap Abstrak, 2, 129-135.

Olivia, F. (2008). Teknik Membaca Efektif. In Teknik Membaca Efektif. Jakarta: Gramedia

Pt, N., Setiawati, Y., Arini, N. W., \& Suarni, N. K. (2017). Pengaruh Model Pembelajaran CIRC berbasis tulisan eksposisi terhadap kemampuan membaca intensif siswa kelas IV. Mimbar PGSD, 5, 2.

Rati, N. W., \& Rediani, N. N. (2018). Pengaruh Model Circ Berbantuan Notes Terhadap Minat Baca dan Hasil Belajar Mahasiswa PGSD Undiksha Singaraja, 2(4), 446454.

Shoimin, Aris. 2014. 68 Model Pembelajaran Inovatif dalam Kurikulum 2013. Yogyakarta. AR-RUZZ Media.

Somadaya, S. (2011). Strategi dan Teknik Pembelajaran Membaca. In Strategi dan Teknik Pembelajaran Membaca (p. 17).

Sudiarni, N. K., \& Sumantri, M. (2019). Pengaruh model pembelajaran CIRC berbantuan penilaian portofolio terhadap keterampilan membaca pemahaman, 2(1), 71-81. 
Sumarni, Y. (2008). Metode Cooperative integrated reading and composition (circ) dalam pembelajaran membaca pemahaman, 2(1), 84-96.

Suryaman, M. (2012). Metodologi Pembelajaran Bahasa. In Metodologi Pembelajaran Bahasa.

Tumbuhan, J., Kelas, D. I., Ipa, X. I., \& Muhammadiyah, S. M. A. (2018). tabel (3,079 > 1,999), 6(1), 54-59.

Utami, P., Darsana, I. W., \& Suadnyana, I. N. (2014). Pengaruh model pembelajaran cooperative integrated reading and composition terhadap hasil belajar IPA siswa kelas V. Mimbar PGSD Undiksha, 2(1).

Yudasmini, n. M., Marhaeni, d. A. I. N., \& Jampel, i. N. (2015). Pengaruh Model Pembelajaran Circ terhadap Minat Baca dan Kemampuan Memahami Bacaan pada Siswa Kelas VI di Sekolah Dasar Gugus Buruan. Jurnal Penelitian dan Evaluasi Pendidikan Indonesia, 5(1).

Yantini, A., Sudiara, I. N. S., \& Astika, I. (2013). Penerapan model pembelajaran cooperative integrated reading and composition(CIRC) untuk meningkatkan kemampuan membaca responsif pada siswa kelas VIII.I smp negeri 1 Gerokgak. E-Journal Undiksha, 4(3), 11.

Yulita, T. (2018). Fakultas ilmu tarbiyah dan keguruan universitas islam negeri raden fatah palembang $2018,1$.

Yunus, A. (2016). Pembelajaran Membaca Berbasis Pendidikan Karakter. In Pembelajaran Membaca Berbasis Pendidikan Karakter (p. 24).

Zulaeha, I. (2016). Pengembangan model pembelajaran keterampilan berbahasa indonesia berkonteks multikultural. Jurnal Penelitian Bahasa, Sastra, Dang Pengajarannya, 12(APRIL 2013), 97-105. 